\section{ECONOMICS}

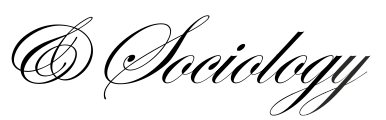

Prabawani, B., Hadi, S. P., \& Hapsari, N. R. (2020). Central Java regional competitiveness: The impacts of production factor, corruption, regulation, and infrastructure. Economics and Sociology, 13(4), 31-42. doi:10.14254/2071789X.2020/13-4/2

\title{
CENTRAL JAVA REGIONAL COMPETITIVENESS: THE IMPACTS OF PRODUCTION FACTOR, CORRUPTION, REGULATION, AND INFRASTRUCTURE
}

\author{
Bulan Prabawani \\ Diponegoro University, \\ Semarang, Indonesia \\ E-mail:bulan@,live.undip.ac.id \\ ORCID 0000-0001-7213-5770
}

\section{Sudharto P. Hadi \\ Diponegoro University, \\ Semarang, Indonesia \\ E-mail: \\ sudhartophadi@,lecturer.undip.ac.id}

\author{
Nurul R. Hapsari \\ UPN Veteran, \\ Surabaya, Indonesia \\ E-mail:nurul.retno.nr@gmail.com
}

Received: January, 2020

1st Revision: September, 2020

Accepted: December, 2020

DOI: $10.14254 / 2071-$

789X.2020/13-4/2

JEL Classification: R1, O1, I5
ABSTRACT. National and regional competitiveness have become important elements for determining investment and regional resilience. A number of indices have been developed as references to determine a sustainable business target. Studies in this direction have also been carried out using various methods, but the majority of them used secondary data, applied different variables, and were not from the perspective of business actors. This research therefore analyzes the influence of production factors, regulation, corruption perception, and infrastructure on the business environment in Central Java, Indonesia, which is a decentralized country. This study applied competitiveness pillars used by the World Economic Forum (WEF) and offered a quantitative approach by carrying out a survey of 1506 companies across various sectors and sizes. Using analysis of moment structures (AMOS) and also robust covariance analysis method, this research has found that even though the city/regency competitiveness is high, there is no significant effect between production factors, regulation, corruption perception, and infrastructure on business environment in the context of regional competitiveness. This proves that primary and secondary data can provide different results and need to complement each other when assessing regional competitiveness.

Keywords: regional competitiveness, production factor, regulation, corruption, business environment, Central Java.

\section{Introduction}

The global competitiveness index is a parameter developed back in 1979 by the World Economic Forum (WEF) to measure productivity, institution, and technical conditions of a country as compared to others. Updated data on this index is released regularly which involves the measurement of three sub-indices (factor-driven, efficiency-driven, and innovation-driven ones) that are then divided into 12 pillars (WEF, 2013). The index is widely used by various parties such as governments, investors, and academics to examine countries' performance and make it a reference for improvement. 
In 2019, the WEF rated Singapore, the US, and Hong Kong as the big three (Schwab, 2019). Indonesia was the 45th with the score of 64.9 in 2018 , but dropped to the 50th position in 2019 with the score of 64.6. In 2018, Indonesia was rated as the country with the worst infrastructure among the G20 countries and among the lower-middle-income countries (WEF, 2018). However, within the last five years, Joko Widodo's government has initiated significant infrastructural development and there has been positive business and entrepreneurship dynamics observed in this regard. Indonesia's macroeconomic stability indicator provided the biggest contribution to the index with the score of 90in both 2018 and 2019, followed by the market size indicator with the score of 82 in 2018 and 82.4 in 2019 (Schwab, 2018, 2019).

In the age of regional autonomy in Indonesia since 1999, and with the existence of central and local financial balance, regional competitiveness has become an important factor for each area and for national competitiveness overall (Holis, Syabri, \& Prabatmojo, 2018). Regional competitiveness is essential for strengthening resilience (Bristow, 2010) as it causes skilled employees' and investments' movement to a more competitive region (OECD, 2019). Decentralization has encouraged the development of infrastructure and regional healthcare facilities (Kis-Katos \& Sjahrir, 2017) since competition now occurres not only at the national level but also at the regional level. Regional competitiveness may result in regional differentiation, namely, whether a region is classified as an underdeveloped one or not. The measurement of regional competitiveness leads to regional policymaking which, in its turn, increases national competitiveness (Januškaite \& Užiene, 2018).

Besides developing natural resources, industrial sector and services, to reach higher competitiveness, Indonesia needs to support adequate educational infrastructure and ICT (Information and Communication Technology) factors (Holis et al., 2018; Ridwan, Hasanuddin, Amri, \& Madris, 2017). This was proven not only by a primary data approach through an expert panel such as in the study that took place in Banten (Holis et al., 2018), but also by a secondary data approach to the macrosector throughout Indonesia (Ridwan et al., 2017). Additionally, Samosir \& Rajagukguk (2017) used secondary data obtained from the Indonesian Database for Policy and Economic Research. The indicators used in this research were GDP (Gross Domestic Product), electrification, mortality, life expectancy, primary education, employment, gender equality, poverty rate, and Gini Coefficient in each region. However, a review of the economy and business outlook, in Central Java specifically, was not highlighted. The secondary data often tends to provide limited, biased information due to the probable differences between the objectives of data collection by the secondary data collector and the objectives of the following users of the same data. Also, secondary data could not be used for scientific hypothesis testing (Trinh, 2018). Moreover, country or regional competitiveness is not always an immediate representation of business competitiveness because countries or regions do not compete with each other as corporations do (Krugman, 1994). Therefore, this research explores the influence of regional competitiveness on the market environment as indicated by the economy and business development using primary data, from the perspective of business practitioners.

\section{Literature review}

Global competitiveness is a description of a country's potential ability to maintain economic growth (Xia, Liang, Zhang, \& Wu, 2012), while regional competitiveness is the capacity of a region to provide an interesting and promising business environment. Regional competitiveness is necessary since it has long-term influence toward economic growth as every area needs to create value for the people living within it. Moreover, regional competitiveness encourages global competitiveness. Competitiveness is also related to productivity (Charles \& 
Zegarra, 2014) or, in this case, is interpreted as business environment. A number of studies have been carried out to identify regional competitiveness. One determined the most competitive region in Peru (Charles \& Zegarra, 2014), another proved that relational proximity influenced regional competitiveness in England (Nicholson, Tsagdis, \& Brennan, 2013), and one showed the presence of a bond between cultural heritage and regional competitiveness in Italy (Alberti \& Giusti, 2012). Country and/or regional competitiveness does not directly affect firm competitiveness, but a number of studies in Peru (Charles \& Zegarra, 2014), the European Union (Bratianu, Dima, Vasilache, \& Talvescu, 2008), Serbia (Kurtovic, Talovic, \& Dacic, 2015), and Australia (McLennan, Becken, \& Watt, 2015) reveal that regional competitiveness contributes to long-term positive growth that is useful for creating value and attracting investment.

In Peru, South America, regions with better infrastructure have higher economic growth whereas the coastal areas have higher competitiveness than the hilly areas. Thus, the Peruvian Government conducted an assessment and ranking of regional competitiveness. (Charles \& Zegarra, 2014). In the European Union, regions with weak business infrastructure and management capabilities also have low welfare. This indicates a weak internal and external business environment so that they are unable to see business opportunities after the integration although this research requires results validation in a better region. (Bratianu et al., 2008). Likewise, in Australia, research by McLennan, Becken, \& Watt (2015) in the context of sustainability programs and using a multi-level interaction cluster theory, shows that regional specificities such as industry specialization can boost business performance. However, individuals, businesses, and clusters have differences in the adaption. The importance of regional competitiveness could be explained using the international trading theory that the regional capacity to compete is based on its ability to develop the economy and business advantages or business environment. The Porter Diamond Theory of National Advantage in international trading explains the roles of many parties and factors surrounding the development of regional competitiveness. The government has a central role as a catalyst in this theory. There are 4 (four) important attributes to improve the competitiveness advantage, namely factor endowments, demand, supporting industries, and firm strategy and/or structure. This approach emphasizes the productivity of a country through innovation, science, and creativity, and not merely on the ownership of natural resources (Porter, 1980). Thus, Porter's Diamond is a framework for increasing the competitiveness of companies at the international level through supports, such as policies and regulations, infrastructure, and resources (Smit, 2010).

Indicators to assess country and/or regional competitiveness are always developing. Some of these include the Current Competitiveness Index, the Growth Competitive Index, and the Business Competitive Index, and earlier on the well-known Global Competitive Index (Lall, 2001; Porter, Delgado, Ketels, \& Stern, 2008). Even the WEF's present standard measurements are considered by economists as skeptical because they are unable to predict future trends, are oversimplified, misleading, and simply quantifying sophisticated phenomena (Lall, 2001), and also do not include elements of cross-border activities (Postelnicu \& Ban, 2010). Hence the measurements have been criticized and modified for certain purposes such as to develop EU competitiveness by highlighting innovation and education (Dima, Begu, Vasilescu, \& Maassen, 2018) or for suggesting new indicators into the measurements. The suggested indicators include entrepreneurial activity and national culture, especially aspects of individualism, power distance (Xia et al., 2012), and corruption perception index or CPI (Ozdemir, 2008). CPI is needed in measuring GCI because the country's credibility in the context of the corruption index affects the currency crisis, as evidenced in research involving CPI in 33 countries cross Asia, Africa, Europe, and America (Ozdemir, 2008). Thus this study will prove how policies, regulations, production factors, and infrastructure influence regional business environment. 


\section{Methodological approach}

This is an exploratory study to test the influence of production factor, regulation, corruption, and infrastructure to the Central Java business environment. This area is 32,548 $\mathrm{km}^{2}$, consists of 35 Cities/Regions, has 4,139,590 companies or $16 \%$ of the total micro, small, middle, and large business population in Indonesia (BPS, 2016).

The population for this research comprised of many types of micro, small, middle, and large businesses from Central Java representing in both the manufacturing and service sectors. The sample, which was collected using a stratified convenience sampling technique, consisted of 1506 companies. The data collection was carried out through a survey. The following is the description of the research samples:

Table 1. Firm age and size

\begin{tabular}{lrrrrrrrr}
\hline Description & \multicolumn{4}{c}{ Firm Age } & \multicolumn{4}{c}{ Firm Size } \\
\hline & $\leq 3$ yrs & $>3-5 y r s$ & $\begin{array}{c}>5- \\
10 y r s\end{array}$ & $>10 y r s$ & Micro & Small & Medium & Large \\
\hline Frequency & 202 & 175 & 336 & 793 & 323 & 613 & 427 & 143 \\
\hline Percentage & $13 \%$ & $12 \%$ & $22 \%$ & $53 \%$ & $21 \%$ & $41 \%$ & $28 \%$ & $9 \%$ \\
\hline
\end{tabular}

Source: own compilation

Majority (75\%) of the companies that were sampled in this study had been operating for more than 5 years; $53 \%$ were more than 10 years old. This confirms that Indonesia had good macroeconomic stability before the Covid 19 pandemic era. As a general characteristic of companies in Indonesia, the majority of the sample, $62 \%$, were either a micro or small business. Only $9 \%$ of the sample comprised of large firms. As seen from the ownership, $61 \%$ of the sample companies were individual-owned, while only $16 \%$ were limited companies.

Table 2. Table 2 Firm business form

\begin{tabular}{|c|c|c|c|c|c|c|}
\hline Description & \multicolumn{6}{|c|}{ Business Form } \\
\hline & Individual & Cooperation & CV/Firms & JV & Ltd & Others \\
\hline Frequency & 917 & 55 & 260 & 21 & 239 & 14 \\
\hline Percentage & $61 \%$ & $4 \%$ & $17 \%$ & $1 \%$ & $16 \%$ & $1 \%$ \\
\hline
\end{tabular}

Source: own compilation

The respondents sampled in the research show that the sampled companies had to be stable and to represent the general characteristics of Indonesian companies, especially with respect to firm size and the form.

This research used the four pillars of WEF, namely institution, infrastructure, workforce market, and business dynamic. The production factor (Prod) was chosen as a representation of the workforce market pillar because the Central Java area is a reference for the manufacturing industry in which each area is competitive in the labor market (Hafiyyan, 2019), so zero-sum games are applied in this area especially with regard to attracting investment. Corruption (Corr) was chosen as a variable because even though Indonesia had a better corruption index from 2010 to 2019, the score later declined to only 40 out of 100 (Tradingeconomics, 2020). Additionally, the corruption index is related to the credibility of the state and has an impact on the currency crisis (Ozdemir, 2008). Regulation (Reg) is an important variable in research because the law in Indonesia is often unable to keep up with community developments quickly and precisely so that the credibility of rule-makers is often questioned (Utari \& Arifin, 2019). 
Infrastructure (Infra) was chosen because Indonesia has a low infrastructure score (WEF, 2018) although this dimension greatly affects business performance (Byrd, Lewis, \& Ford, 2005; Portugal-Perez \& Wilson, 2012). The endogen variable is the perception of business actors on economic and business conditions in their respective regions. The better the business actor's assessment of the regional business and economic conditions the higher their confidence. The business environment is measured by business and economic conditions in order to assess present conditions, and business outlook to predict future trends (Lall, 2001).

The competitiveness pillars were then formed in a model consisting of four exogenous variables: production factor (Prod), corruption (Corr), regulation (Reg), and infrastructure (Infra), as well as an endogenous variable namely business environment (Buss). For each variable, there were two to three manifests.

Table 3. The measurements

\begin{tabular}{ll}
\hline & Variable \\
\hline Production Factor & A1 Labor \\
(Prod) & A2 Production Technique \\
\hline Corruption & B1 Corruption \\
(Corr) & B2 Illegal Levy \\
\hline Regulation & B3 Law Consistency \\
(Reg) & B4 Law Enforcement \\
\hline Infrastructure & C1 Electrification \\
(Infra) & C2 Transportation \\
\hline Business environment & Y1 Economic Condition \\
(Buss) & Y2 Business Condition \\
& Y3 Business Outlook \\
\hline
\end{tabular}

Source: own compilation

Data analysis was done using structural equation modeling of analysis of moment structures or AMOS. The use of covariant-based multivariate analysis tools was intended to not only determine the relationships between variables, but also that between manifests, hence manifests or indicators' validity and reliability are important concerns in AMOS. In addition, AMOS is robust against non-normal data, which is important because this study involved a high variety of businesses from 35 different regions in Central Java, across various sectors, and firm sizes. To get a valid model, this study sets the cut-offs for CMIN/df $<2$; RMSEA <.08; RMR $<.06$, and CFI >.90 (Kline, 2011; Tabachnick \& Fidell, 1996).

\section{Conducting research and results}

This research was carried out to prove the Porter Diamond Theory (Porter, 1980) at the regional level, as well as to strengthen previous research that used macro economy indicators (Samosir \& Rajagukguk, 2017; Schwab, 2018; WEF, 2013). The previous studies used secondary data as applied at the national level (Schwab, 2018) and only focused on one single area (Holis et al., 2018). However, the research is still using concepts that, according to Bristow (2010), have been de-contextualized such as labor and inward investment compared to mutual linkages, or the roles of policy and institutions as compared to utilizing local knowledge.

Production factors and the role of the government, in this case, had theoretically become an exogenous variable and are referred to in previous research influencing business environment (Januškaite \& Užiene, 2018; Ketels, 2015). The research placed the government as an important factor of regional competitiveness. 
Central Java consisted of 35 regions, they were Banjarnegara (BJM), Banyumas (BMS), Batang (BTG), Blora (BLR), Boyolali (BYL), Brebes (BRB), Cilacap (CLP), Demak (DMK), Grobogan (GRB), Jepara (JPR), Karanganyar (KRA), Kebumen (KBM), Kendal (KDL), Klaten (KLT), Kudus (KDS), Magelang rg (MGLR), Magelang ct (MGLC), Pati (PTI), Pekalongan rg (PKLR), Pekalongan ct (PKLC), Pemalang (PML), Purbalingga (PBG), Purworejo (PWR), Rembang (RBG), Salatiga (SLG), Semarang rg (SMGR), Semarang ct (SMGC), Sragen (SRA), Sukoharjo (SKH), Surakarta (SKR), Tegal rg (TGLR), Tegal ct (TGLC), Temanggung (TMG), Wonogiri (WRG), Wonosobo, WSB). The regional competitiveness in Central Java by companies representing 35 regencies/cities, and representatives throughout the sector using the indicators of corruption and regulation as follows:

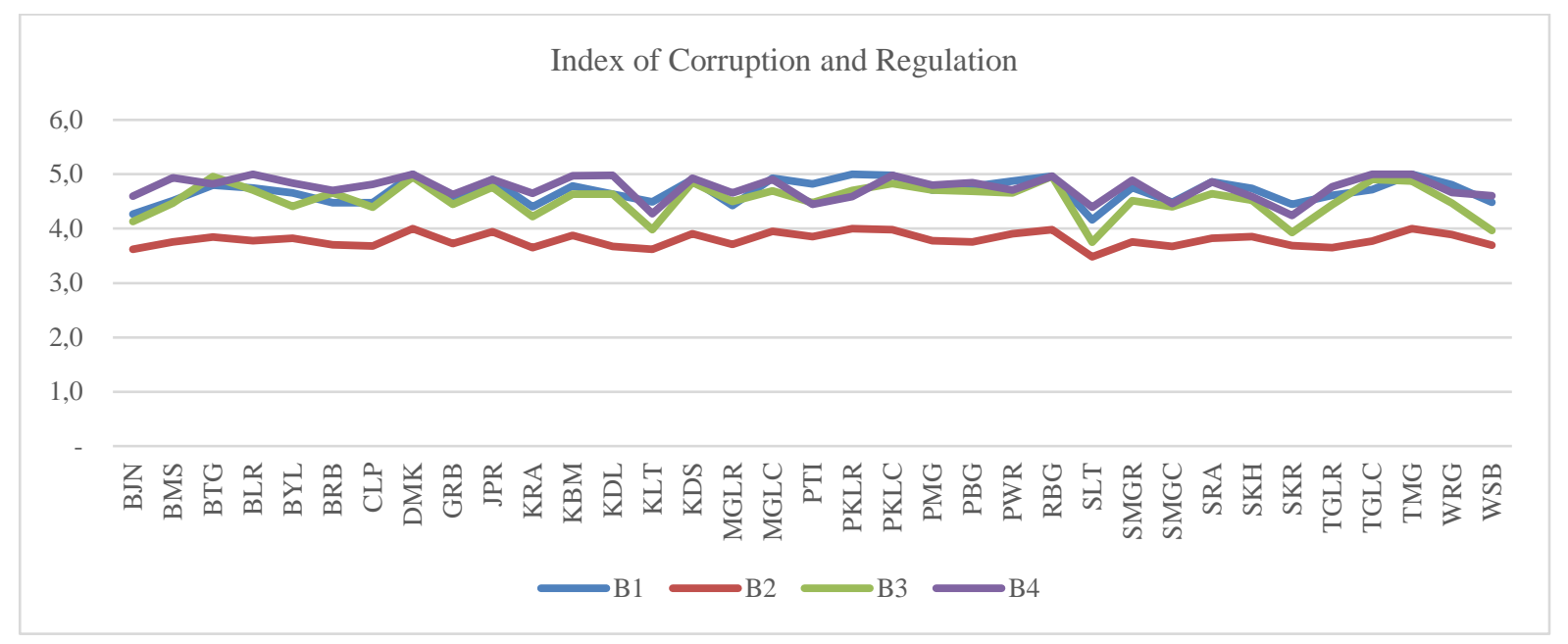

Graph 1. Index of corruption and regulation

Source: own data

Referring to Graph 1, all indicators for both corruption and regulation were considered fair (min score of 3.5) to very good (max score of 5.0) by business people. There was a tendency for the good areas to have all high-value indicators, in contrast, the moderate areas had low trend values for all indicators. Illegal levy (B2) was the lowest assessed indicator while law enforcement (B4) were the best indicators. The best areas for anti-corruption performance were Demak, Temanggung, Rembang, Pekalongan City, and Pekalongan Regency with a score of 4.5. The best areas for implementation of regulation were Demak, Rembang, and Tegal City with a perfect score of 5.0.

The index of Central Java regional competitiveness with indicators of production factors and infrastructure as follows: 


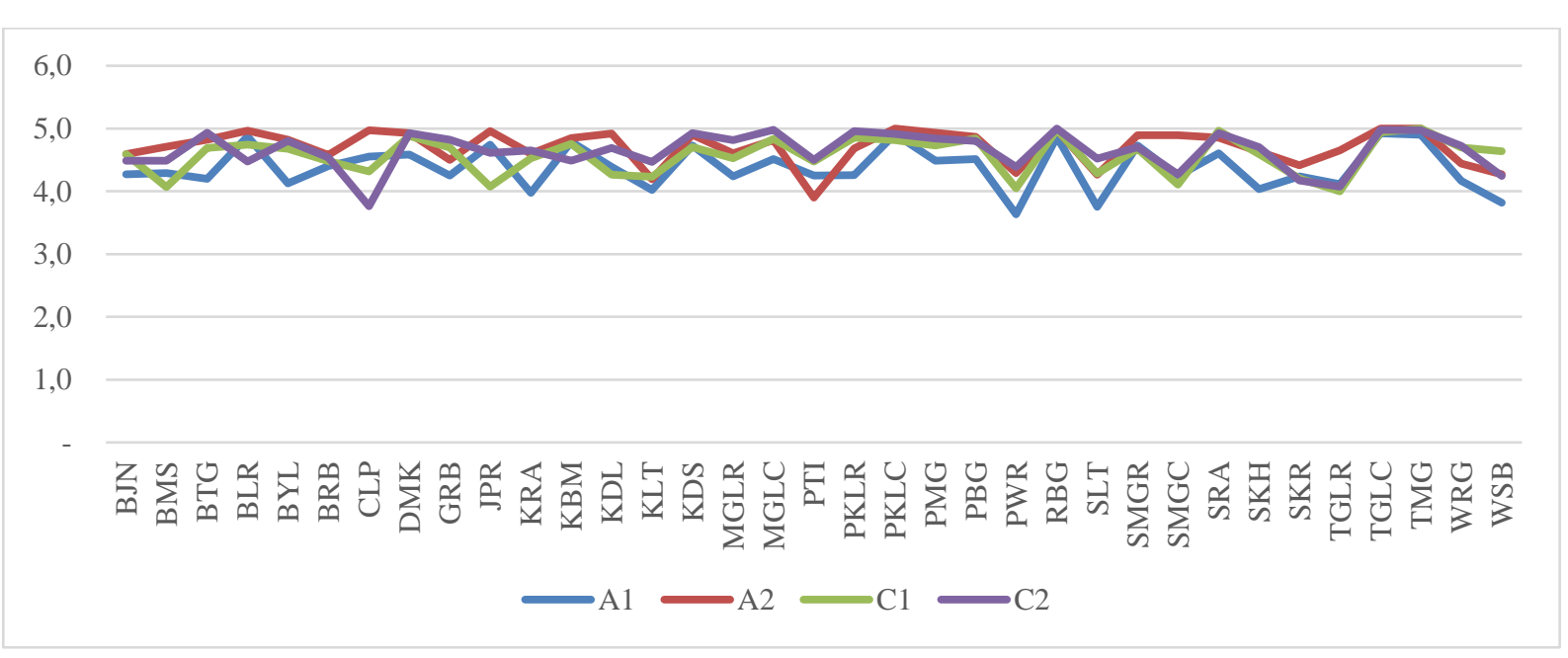

Graph 2. Index of production factor and infrastructure Source: own data

Referring to Graph 2, all indicators-whether production factors and infrastructure-were considered as sufficiently/relatively good throughout all regencies/cities in Central Java, with an average score of 4.6 out of 5 scales. All indicators were also assessed as fair (min score of 3.6 ) to very good (max score of 5.0) by business people. Different to the variables of corruption and regulation, there was no strong tendency of performance consistency at the variable of production factor and infrastructure from the areas. The best areas for production factor were Pekalongan City, Tegal City, and Temanggung with a score of 5.0. The best areas for infrastructure were Rembang, Tegal City, and Temanggung with a perfect score of 5.0.

The indicators considered the best were production factor (A2), corruption (B1), and law enforcement (B4). This marks the role of government as the first pillar in regional competitiveness, confirming Porter's argument that the government is a catalyst that has a role in creating a competitive environment for industry (Januškaite \& Užiene, 2018) through its main functions in keeping the power (Benzaquen, et al., 2010). Therefore, the regions in Central Java with high resilience, on mutuality, were those with high scores reflecting support from government in the form of clarity and law enforcement. The Temanggung, Tegal, and Rembang Governments, in this study, have made commitments to creating a favorable climate for starting and encouraging business. Its success can be seen from evaluation results of the bureaucratic reform implementation, which increased from "fair performance" (score of $>50-65$ ) to "good performance" (score of $>65-75$ ) in 2019. Temanggung government is also preparing a number of regulations to encourage business development (Rohman, 2019).

Referred to Liu \& Hsu (2009), labor and production techniques are fundamental elements in achieving competitiveness. It means that in regions where regional resilience was lowest, there was need to improve comparative competitiveness through the development of mutual linkages. In other words, the government and business parties needed to collaborate. The government should make policies for the benefit of employment and attract industries to invest. These would accelerate technology transfer. Efforts to increase competitiveness would make the workforce and business more productive. The influence between the exogenous variables and business environment is described by the following model: 


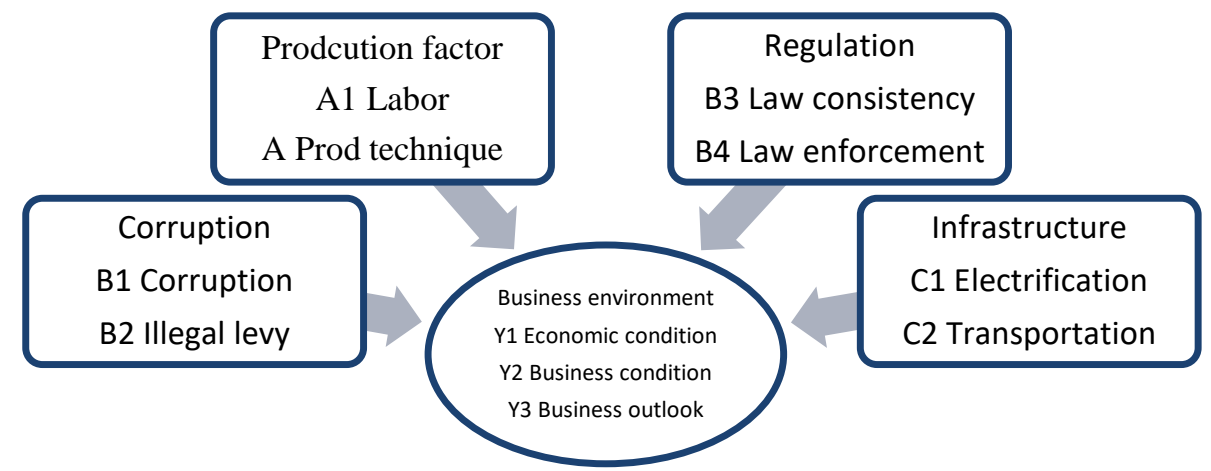

Fig. 1. The Conceptual Model

The structural equation modeling output using AMOS shows that the model is valid and reliable. Each manifest representative explains both the exogenous and endogenous variables with a 0.5 factor loading cut-off. The significant model has high fit where CMIN/df is 1.349 or <2.0, RMR: 0.010 or <0.060, GFI: 0.995, and CFI: 0.997 or $>0.950$, also the RMSEA is 0.015 or $<0.05$ (Kline, 2011; Tabachnick \& Fidell, 1996).

Table 4. The Model Validity and Reliability

\begin{tabular}{lllrrr}
\hline & & & Estimate & AVE & $\begin{array}{c}\text { Discriminant } \\
\text { Validity }\end{array}$ \\
\hline Business Environment & $<---$ & Production Factor & 0.009 & & \\
Business Environment & $<---$ & Infrastructure & 0.085 & & \\
Business Environment & $<---$ & Regulation & -0.137 & & \\
Business Environment & $<---$ & Corruption & 0.061 & & 0.663 \\
\hline Y1 Economic condition & $<---$ & Business Environment & 0.547 & 0.439 & \\
Y2 Business condition & $<---$ & Business Environment & 0.821 & & \\
Y3 Business outlook & $<---$ & Business Environment & 0.587 & & 0.926 \\
\hline B1 Corruption & $<---$ & Corruption & 0.994 & 0.857 & \\
B2 Illegal levy & $<---$ & Corruption & 0.852 & & 0.651 \\
\hline B3 Law Consistency & $<---$ & Regulation & 0.641 & 0.423 & \\
B4 Law Enforcement & $<---$ & Regulation & 0.660 & & 0.588 \\
\hline A1 Labor & $<---$ & Production Factors & 0.551 & 0.345 & \\
A2 Production Technique & $<---$ & Production Factors & 0.622 & & 0.646 \\
\hline C1 Electricity & $<---$ & Infrastructure & 0.630 & 0.417 & \\
C2 Transportation & $<---$ & Infrastructure & 0.661 & & \\
\hline
\end{tabular}

Source: own compilation

However, the measurement models are relatively less valid and reliable that the values of the Average Variance Extracted and the Discriminant Validity are under 0.5 and 0.7 , respectively (see Table 4). The only variable that has high validity and reliability is the corruption. The model explains that the influence of production factors, regulation, levy, and infrastructure on such business environment is acceptable. However, all exogenous variables do not influence business environment. 
Table 5. Results for Structural Equation Analyses

\begin{tabular}{lrrrrc}
\hline \multicolumn{1}{c}{ Path } & Estimate & \multicolumn{1}{c}{ S.E. } & \multicolumn{1}{c}{ C.R. } & \multicolumn{1}{c}{ P } & Label \\
\hline Buss $\leftarrow$ Prod &, 006 &, 067 &, 088 &, 930 & No significant \\
\hline Buss $\leftarrow$ Corr &, 027 &, 020 & 1,366 &, 172 & No significant \\
\hline Buss $\leftarrow$ Reg &,- 080 &, 067 & $-1,199$ &, 230 & No significant \\
\hline Buss $\leftarrow$ Infra &, 052 &, 030 & 1,731 &, 083 & No significant \\
\hline
\end{tabular}

Source: own compilation

Therefore, this research used primary data at the regional level to show that the Porter Diamond Theory (Porter, 1980) is not effective in the business perspective. This research has also tried to compare the influence of the variables that might be different among the firm sizes, also among the cities/regencies having a high index of competitiveness. Still, however, there are no significant differences within the sample group. Hence, there is no tendency that the region with production factors, low corruption, law enforcement, and good infrastructure may be a good predictor of business environment. This has emphasized the opinion of Bristow (2010) that the concept of competitiveness index has been de-contextualized, while business and economic needs advanced supports such as mature financial markets, research, and innovation development.

Statistically, this research shows that the type of data, whether it is secondary or primary, explains different phenomena in analyzing regional competitiveness. Heterogeneity of a population with complex backgrounds does not make any difference in the result of a significant model. Likewise, model testing by only involving highly competitive areas also does not provide significant influence among variables.

Theoretically, this research proves that de-contextualized competitiveness enables the occurrence of a different research result. Therefore, further research is expected to develop a similar model with contextualized competitiveness, where the concept of competitiveness is adjusted to the charge of resilience, recalling the intense change of economy and business. Additionally, further research is needed to test other regions, recalling competitiveness attached to "place" (Bristow, 2010) or "location aware" (Ketels, 2015).

The concept by Ketels (2015), seems to have been developed in Indonesia where each area has an industry specialization, especially in Java. Central Java is concentrated in the beverages industry (Semarang), textile (Semarang, Kudus, Sukoharjo, Karanganyar), wood (Jepara), and chemicals (Sukoharjo and Karanganyar) with a high specialization value (the second-highest) compared to other provinces in Indonesia. Moreover, there is a high industrial disparity in Central Java (Claudia, 2017; Kusumantoro, 2012). Thus, further studies need to be carried out by developing different indicators for each region. In addition, a preliminary study is needed to draw the actual needs of each different industry.

The industrial specialization in Central Java has become increasingly relevant in the midst of the decentralization era that presents the region as having greater authority over the industry, compared to the national government. Each region in Indonesia has higher discretion to determine factor such as minimum wages, taxes, and other policies related to the industry. Moreover, Indonesia is no longer classified as a developing country but an advanced country. It would have higher challenges for business; hence the industry must have competitive advantages. Indonesia's superiority in market size and macroeconomic stability (Schwab, 2018, 2019) will benefit investors in general, and even become a niche market for global investors who are competitors for local investors. To improve its competitive advantage, local governments must encourage and facilitate industrial innovation and R\&D. In addition, labor 
efficiency and technological competence need to be improved so as to encourage the area to be more favorable for investors.

\section{Conclusion}

Regional competitiveness is an important dimension considered by businesses and politics in determining investment, thus a competitive index becomes the reference and fosters the national competitiveness index. Even though a number of previous studies with secondary data found that competitiveness influences, for example, economic growth and resilience, research using primary data found that a number of competitive dimensions do not influence business and economic performances. Although regions in Central Java have a high factordriven competitiveness index, according to the business actors, the competitiveness index does not affect business and economic performance in their respective regions. Therefore, the Porter Diamond Theory of National Advantage needs to be considered with other approaches for further research, such as the evolution in cultural political economy and/or use higher stages of competitiveness index indicators, they are efficiency and innovation-driven. This is relevant to the current condition of Indonesia that has been classified since 2020 no longer as a developing country, but as an advanced country. For example, market size as an efficiency-driven indicator, is one of Indonesia's strengths in the competitiveness index. Thus, market and labor efficiency, technological readiness, as well as innovation are more relevant. In addition, updated data is essential after economic recovery post the pandemic era. The business environment is however a variable that is too broad so that it needs to be developed into a more detailed indicator.

\section{Acknowledgement}

We would like to thank to the Diponegoro University for the research funding no. 379/UN7.5.7/HK/2019.

\section{References}

Alberti, F. G., \& Giusti, J. D. (2012). Cultural heritage, tourism and regional competitiveness: The Motor Valley cluster. City, Culture and Society, 3(4), 261-273. https://doi.org/10.1016/j.ccs.2012.11.003

Benzaquen, J., Carpio, L. A. D., Zegarra, L. A., \& Valdivia, C. A. (2011). A competitiveness index for the regions of a country. Cepal Review, 2011(102), 67-84. https://doi.org/10.18356/7781698b-en

BPS (2016). Economic census 2016. Retrieved February 26, 2019, from Sensus Ekonomi 2016 websitehttps://se2016.bps.go.id/umkumb/

BPS (2020). Development of exports and imports of Central Java Province in December 2019. Semarang: Jawa Tengah

Bratianu, C., Dima, A. M., Vasilache, S., \& Talvescu, D. (2008). The impact of business strategy on regional sustainable development. The Business Review, 11(1), 288-295. https://doi.org/10.1108/JSMA-06-2014-0042

Bristow, G. (2010). Resilient regions: Replacing regional competitiveness. Cambridge Journal of Regions, Economy and Society, 3(1), 153-167. https://doi.org/10.1093/cjres/rsp030

Byrd, T. A., Lewis, B. R., \& Ford, F. N. (2005). An empirical study of the relationships between IT infrastructure flexibility, mass. Data Base for Advances in Information Systems, 36(3), $26-44$ 
Charles, V., \& Zegarra, L. F. (2014). Measuring regional competitiveness through Data Envelopment Analysis: A Peruvian case. Expert Systems with Applications, 41(11), 5371-5381. https://doi.org/10.1016/j.eswa.2014.03.003

Claudia, C. A. (2017). Specialization and spatial concentration of the manufacturing industry in Indonesia in 2007-2013. Jurnal Ilmu Ekonomi, 1(1991), 225-239

Dima, A. M., Begu, L., Vasilescu, M. D., \& Maassen, M. A. (2018). The relationship between the knowledge economy and global competitiveness in the European Union. Sustainability, 10(6), 1-15. https://doi.org/10.3390/su10061706

Hafiyyan (2019). Investors consider these five measures to invest in Central Java. bisnis.com. Retrieved from https://semarang.bisnis.com/

Holis, Y. M., Syabri, I., \& Prabatmojo, H. (2018). An examination of regional competitiveness: Early findings from Banten, Indonesia. IOP Conference Series: Earth and Environmental Science, 158(1). https://doi.org/10.1088/1755-1315/158/1/012050

Januškaite, V., \& Užiene, L. (2018). Intellectual capital as a factor of sustainable regional competitiveness. Sustainability, 10(12). https://doi.org/10.3390/su10124848

Ketels, C. (2015). Upgrading regional competitiveness: What role for regional governments? In R. Huggins \& P. Thompson (Eds.), Handbook of Region and Competitiveness, (pp. 501-517). Retrieved from https://doi.org/https://doi.org/10.4337/9781783475018.00002

Kis-Katos, K., \& Sjahrir, B. S. (2017). The impact of fiscal and political decentralization on local public investment in Indonesia. Journal of Comparative Economics, 45(2), 344365. https://doi.org/10.1016/j.jce.2017.03.003

Kline, R. B. (2011). Principles and Practice of Structural Equation Modelling (3rd ed.). New York: Guilford Press

Krugman, P. (1994). Competitiveness: A dangerous obsession. Foreign Affairs, 73(2), 28. https://doi.org/10.2307/20045917

Kurtovic, S., Talovic, S., \& Dacic, L. (2015). Global competitiveness indicators as a determinant of brownfield investments in Serbia: Generalized linear model. Research in World Economy, 6(3), 1-13. https://doi.org/10.5430/rwe.v6n3p1

Kusumantoro. (2012). Disparity and specialization of manufacturing industry in Central Java. JEJAK: Jurnal Ekonomi dan Kebijakan, 2(2), 104-113. https://doi.org/10.15294/jejak.v2i2.1463

Lall, S. (2001). Competitiveness indices and developing countries: An economic evaluation of the global competitiveness report. World Development, 29(9), 1501-1525. https://doi.org/10.1016/S0305-750X(01)00051-1

Liu, D.-Y. Y., \& Hsu, H.-F. F. (2009). An international comparison of empirical generalized double diamond model approaches to Taiwan and Korea. Competitiveness Review, 19(3), 160-174. https://doi.org/10.1108/10595420910962043

McLennan, C. J., Becken, S., \& Watt, M. (2015). Learning through a cluster approach: Lessons from the implementation of six Australian tourism business sustainability programs. Journal of Cleaner Production, 111, 348-357. https://doi.org/10.1016/j.jclepro.2015.01.085

Nicholson, J., Tsagdis, D., \& Brennan, R. (2013). Industrial Marketing Management the structuration of relational space: Implications for firm and regional competitiveness. Industrial Marketing Management, 42(3), 372-381. https://doi.org/10.1016/j.indmarman.2013.02.013

OECD (2019). Regional competitiveness. Retrieved February 21, 2019, from http://www.oecd.org/cfe/regional-policy/regionalcompetitiveness.htm

Ozdemir, B. K. (2008). Investigating the influence of country credibility on the chance of currency crisis. International Journal of Business and Finance Research, 2(2), 117-126. 
Porter, M. E. (1980). Competitive strategy: Techniques for analyzing industries and competitors. In Competitive Strategy: Techniques for Analyzing Industries and Competitors. https://doi.org/10.4324/9781912281060.

Porter, M. E., Delgado, M., Ketels, C., \& Stern, S. (2008). Moving to a New Global Competitive Index. In. The global competitiveness Report 2008-2009 (Vol. Geneva: World Economic Forum. 32, (pp. 43-63).

Portugal-Perez, A., \& Wilson, J. S. (2012). Export performance and trade facilitation reform: Hard and soft infrastructure. World Development, 40(7), 1295-1307. https://doi.org/10.1016/j.worlddev.2011.12.002.

Postelnicu, C., \& Ban, I. M. (2010). Some empirical approaches of the competitiveness' diamond-the case of Romanian economy. Romanian Economic Journal, 13(36), 53-77.

Ridwan, Hasanuddin, B., Amri, M., \& Madris (2017). The determinants of regional competitiveness. Scientific Research Journal (SCIRJ), 5(12), 48-55. https://doi.org/10.5465/ambpp.2015.13549symposium.

Rohman, M. A. (2019). The increasing index of Temanggung bureaucracy reform. February 3 , 2020, Suara Merdeka Website. Retrieved from https://www.suaramerdeka.com.

Samosir, O. B., \& Rajagukguk, W. (2017). Regional Competitiveness and National Economic Growth. Economic Reforms for Global Competitiveness, (January), 306-328. https://doi.org/10.4018/978-1-5225-3856-1.ch016.

Schwab, K. (2018). Insight report the global competitiveness report 2018. Retrieved from http://www3.weforum.org.

Schwab, K. (2019). Insight Report. World Economic Forum.

Smit, A. J. (2010). The competitive advantage of nations: Is Porter's Diamond Framework a new theory that explains the international competitiveness of countries? Southern African Business Review, 14(1), 105-130. https://doi.org/10.1088/0953-8984/22/19/194103.

Tabachnick, B. G., \& Fidell, L. S. (1996). Using multivariate statistics. In Harper Collins. https://doi.org/10.1037/022267.

Tradingeconomics (2020). Indonesia Corruption Index.

Trinh, Q. D. (2018). Understanding the impact and challenges of secondary data analysis. Urologic Oncology: Seminars and original investigations, 36(4), 163-164. https://doi.org/10.1016/j.urolonc.2017.11.003.

Utari, I. S., \& Arifin, R. (2019). Law enforcement and Legal reform in Indonesia and global context: How the law responds to community development? Journal of Law \& Legal Reform, 1(1), 1-4.

World Economic Forum (2013). The global competitiveness index-what is measured. Retrieved from http://www.economy.ge/uploads/ek_ciprebshi/reitingebi/reitingebi_eng/gci.pdf

World Economic Forum (2018). The global competitiveness report 2018. Retrieved from https://doi.org/92-95044-35-5. In. World Economic Forum, 5.

Xia, R., Liang, T., Zhang, Y., \& Wu, S. (2012). Is global competitive index a good standard to measure economic growth? A suggestion for improvement. International Journal of Services and Standards, 8(1), 45-57. https://doi.org/10.1504/IJSS.2012.048438. 